\title{
Techniques for Quality Control in Football Field Located in Agricultural Area
}

\author{
Marta Mitiko Kubota de Siqueira ${ }^{1}$, Márcio Antonio Vilas Boas ${ }^{1}$, Jair Antonio Cruz Siqueira ${ }^{2}$ \\ \& Luciene Kazue Tokura ${ }^{2}$ \\ ${ }^{1}$ Graduation Program, Master's in Agricultural Engineering, State University of West Parana, Cascavel, Parana, \\ Brazil \\ ${ }^{2}$ Graduation Program, Master's in Engineering of Energy in Agriculture, State University of West Parana, \\ Cascavel, Parana, Brazil \\ Correspondence: Marta Mitiko Kubota de Siqueira, Graduation Program, Master's in Agricultural Engineering, \\ State University of West Parana (UNIOESTE), Rua Universitária, 2069, Jardim Universitário, CEP: 85819-110, \\ Cascavel, Parana, Brazil. Tel: 55-(45)-3220-7390. E-mail: martamks@gmail.com
}

Received: May 29, 2018

doi:10.5539/jas.v10n9p430
Accepted: July 3, $2018 \quad$ Online Published: August 15, 2018

URL: https://doi.org/10.5539/jas.v10n9p430

\begin{abstract}
A set of eight sprinklers was evaluated in a soccer field located in the city of Cascavel, Paraná, Brazil, using quality control techniques. The graph $\bar{X}$ (Shewhart's individual control card), the EWMA graph (exponentially weighted moving average) and the CUSUM tabular graph (cumulative sum) were used. The system was composed of two parallel lateral lines distanced of 18 meters, containing five sprinklers in each line every 18 meters. The first four sprinklers (area A) and the last four (area B) were evaluated with 25 trials of 10 minutes of irrigation for each area, with the monitoring of climatic effects. For the evaluation of the system, the distribution uniformity coefficient (DU) was used, obtaining in the area A and B the values of 68.72 and $70.0 \%$. This low value can be justified by the high wind velocity during the tests, that varied from 0.57 to $8.5 \mathrm{~m} \mathrm{~s}^{-1}$. By Shewhart's control chart, the irrigations of both areas were under control. From the CUSUM chart, only area B was under control. From the EWMA chart, both areas were out of control, being considered the most suitable for evaluation of the system because it detected the small variations in the process.
\end{abstract}

Keywords: distribution uniformity, Shewhart control chart, CUSUM control chart, EWMA control chart

\section{Introduction}

Soccer fields are common in residential condominiums, clubs and sports associations built in urban or rural areas. Most are made up of grasses that, according to García-González et al. (2015), have high water requirements throughout the year. In this sense, besides the choice of the ideal grass for the field, it is necessary to use an efficient irrigation system.

For Bernardo (1995), sprinkler irrigation adapts to almost all types of crops, but wind, relative humidity and temperature are the main climatic factors that affect its use, which reduce the uniformity of application irrigation.

On the other hand, Coelho et al. (2018) point out that irrigation systems with high water application uniformity with irrigation deficit are some ways to increase the efficiency of water use, providing less water without significantly affecting the crop. Thus, it is fundamental that in the irrigation of soccer fields, being an area with great demand of water, are used low volumes of water, promoting water saving and at the same time, keeping the lawn with uniform aspect in all its extension.

For Mantovani, Bernardo, and Palaretti (2007) it is extremely important to perform water application uniformity tests to identify the fraction of water sprayed in excess or with water deficit.

However, irrigation research aimed mainly on crop productivity has been the focus of several authors, such as the Atroosh et al. (2018) However, it is necessary to know the uniformity of water distribution provided by the equipment used in the irrigation to obtain a more uniform productivity of the crop. 
According to Zhang and Merkley (2012), the application of control graphs using the distribution uniformity coefficient (DU) has been one of the ways to monitor the irrigation system, which is one of the most common indicators of uniformity application of irrigation water.

For Montgomery (2009), control charts are tools that monitor the mean and variability of the quality characteristic in observation. It also points out that the Shewhart control chart is very effective when the magnitude of the change is greater than $1.5 \sigma$, presenting the disadvantage of being insensitive to small variations in a process. The EWMA (exponentially weighted moving average) and CUSUM (cumulative sum) graphs are recommended because they are more sensitive, which can identify small deviations from the average of a process.

The irrigation system can also be evaluated from the capacity index of the process, which according to Costa, Epprecht and Carpinetti (2005), is a dimensionless parameter that indirectly measures how much the process can meet the specifications.

It should be noted that control charts and process capability index are tools commonly used in process analysis of several areas of knowledge, such as the Justi, Vilas Boas, and Sampaio (2010) in irrigation and Saldanha et al. (2015) in the process of a chemical industry.

In this context, the objective of this work was to evaluate the irrigation system of a soccer field located in the city of Cascavel, Paraná, Brazil, using Shewhart, EWMA and CUSUM control charts, to evaluate the system in question.

\section{Material and Methods}

\subsection{Location Characterization}

The research was carried out in the football field of the Coopavel Athletic Association, located at BR 467, Km 106 in the city of Cascavel, Paraná, Brazil, with geographical coordinates of $24^{\circ} 54^{\prime} 38^{\prime \prime} \mathrm{S}$ and $53^{\circ} 29^{\prime} 27^{\prime \prime} \mathrm{W}$ at 750 meters altitude. According to the classification of Köppen-Geiger, the climate of the region is Cfa, subtropical humid, with average temperature of $18.2^{\circ} \mathrm{C}$ and average annual rainfall of $1822 \mathrm{~mm}$.

\subsection{Implantation and Conduct of the Experiment}

The field is surrounded in all its entire contour, having on the east face a concrete grandstand, presenting on the other faces a dense reforestation of eucalyptus, as shown in Figure 1. It is 72 meters wide and 105 meters long, positioned longitudinally in the north-south direction on level terrain, consisting in all its extension by grass of the Esmeralda type (Zoysia japonica). It was built in 2006 and since then has been used the same irrigation system adopted at the time.

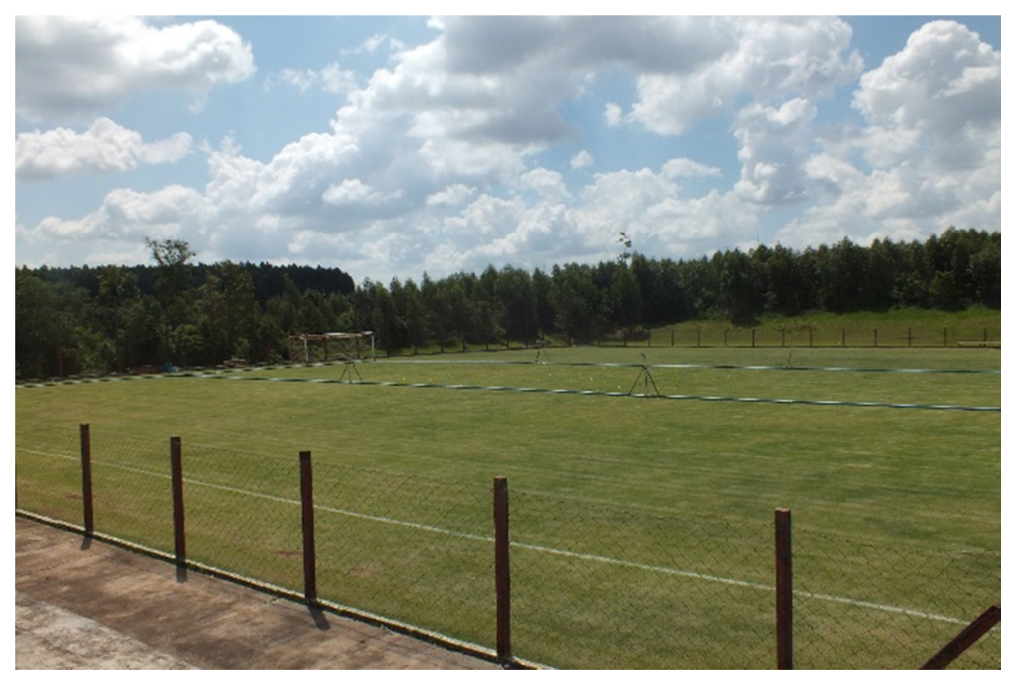

Figure 1. Football field and its surroundings 
The system is composed of two parallel lateral lines, distanced of 18 meters. In each line were distributed five sprinklers every 18 meters, totaling 10 sprinklers of the mini cannon type of the brand PLONA KS1500. All the sprinklers were positioned 2 meters in height in relation to the ground, supported by metallic supports.

The water used for irrigation comes from a water box of 20.000 liters, located on the south face of the field, which is supplied by an artesian well, the water being sent to the irrigation system from a motor pump set of 15 CV.

\subsection{Installed Equipment}

The climatic data regarding temperature $\left({ }^{\circ} \mathrm{C}\right)$, relative humidity of air $(\%)$ and wind speed $\left(\mathrm{m} \mathrm{s}^{-1}\right)$ were collected by a mini meteorological station, of the brand Instrutemp-ITWH 1080, positioned to the height of 2 meters of the level from soil. The equipment was programmed to transmit the weather data every 5 minutes via wireless to the respective receiver and transferred to an excel spreadsheet to enable data evaluation.

The pressures in each sprinkler were measured with a Bourdon tube manometer in unit $\mathrm{kPa}$. The average pressures were obtained from three readings at each sprinkler.

The first four sprinklers denominated by area $\mathrm{A}$ and the last four sprinklers denominated area $\mathrm{B}$, which are presented in Figure 2, was analyzed. The figure also presents in a schematic form, the characteristics of the field and its surroundings, the position of the water box, set moto bomb, meteorological station, data receiver and bleachers.

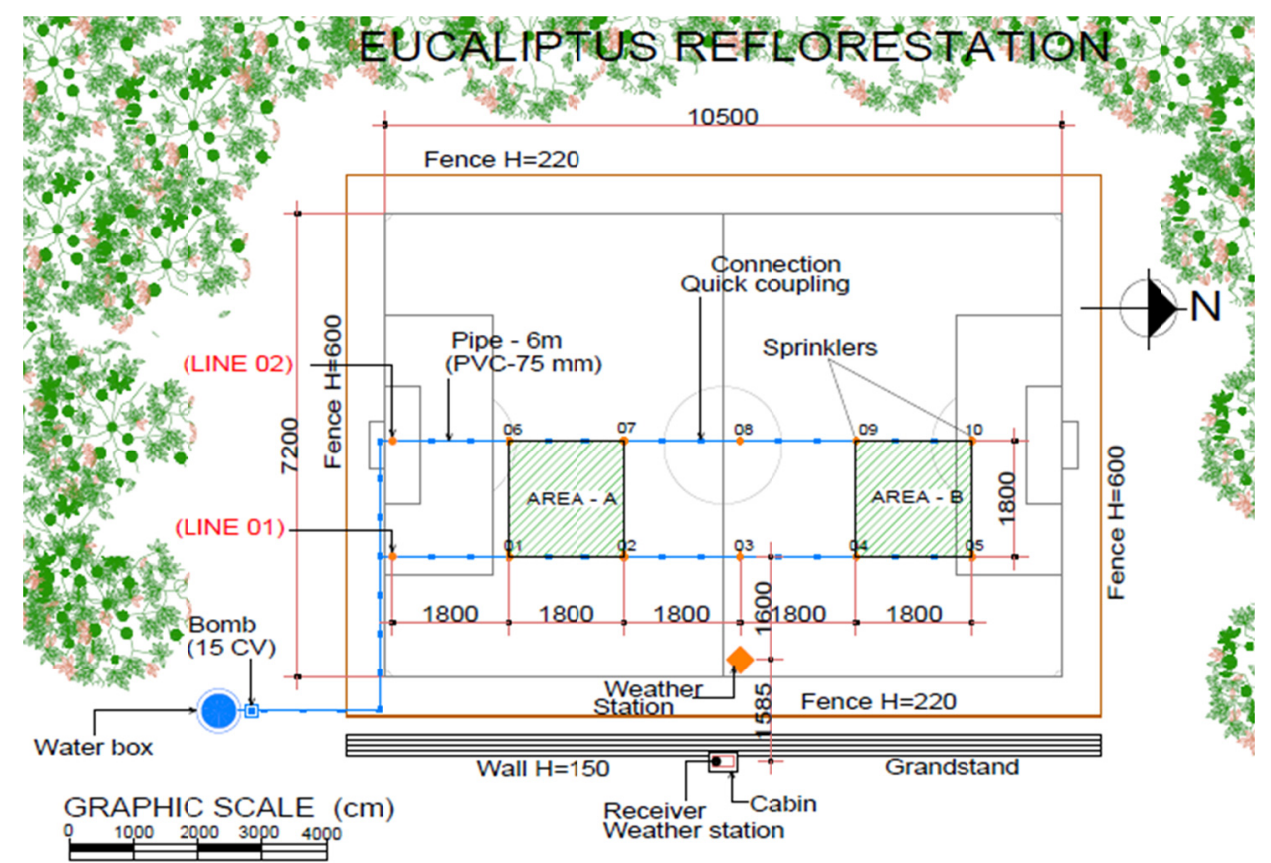

Figure 2. Position of areas A and B of the weather station and its data receiver

\subsection{Analyzed Variables}

The trials for data collection started on October 23, 2015 and ended on November 11, 2015, performed in the morning and afternoon periods on non-rainy days.

In each area, 25 trials were performed using Fabrimar brand plastic collectors, with a top face diameter of 8.03 $\mathrm{cm}$ and $8 \mathrm{~cm}$ in height. The plastic collectors were arranged on the lawn level to get the volume of water that fall on the grass. Thus, they were arranged at 2 meters between each other (ABNT NBR ISO 7749-2, 2000), with their base on the level of the lawn, inserted in metallic supports to avoid their tipping, obtaining a total of 81 collectors in each area. The water depth of each collector was measured with a graduated glass beaker, in $\mathrm{mm} \mathrm{h}^{-1}$.

The Figure 3 shows the position of the collectors in relation to the sprinkler positioned in each area, containing the respective distances. 


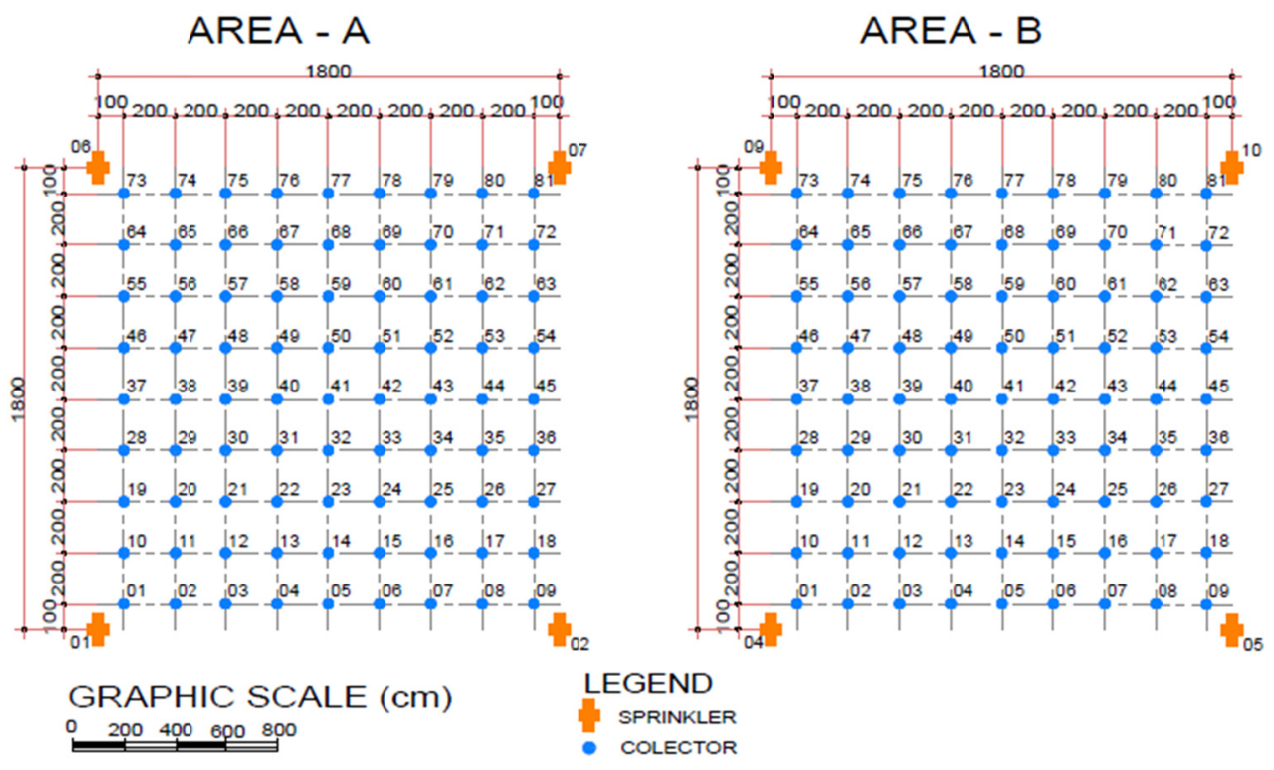

Figure 3. Collector and sprinkler positions in areas A and B

For the calculation of uniformity of water distribution, the tests shall be 1 hour, in accordance with ISO 7749-2: 2000. However, the time of 10 minutes was stipulated for each lateral line, because the volume of the water box was not sufficient to be a longer time. It is noteworthy that in all trials, sprinklers number 3 and 8 , located between areas A and B, were also submitted to irrigation, which contribute to the uniformity of distribution in the two areas under study.

With the water depth collected in the two areas, the distribution uniformity coefficients (DU) were calculated from Equation 1:

$$
D U=100 \cdot \frac{x_{25}}{x_{\text {med }}}
$$

Where, $D U=$ distribution uniformity coefficient, in $\% ; x_{25}=$ mean of the lowest quartile of the volumes of water contained in the collectors, in $\mathrm{mm} ; x_{\text {méd }}=$ average of the values of the volumes of water collected, in $\mathrm{mm}$.

According to DU values, Keller and Bliesner (2009) classified them as excellent, above 90\%; good, between 85 and $90 \%$; acceptable up to $65 \%$ and unacceptable, below $65 \%$.

To identify whether or not the treatments are under statistical control, the Shewhart control charts for individual measures, the CUSUM and EWMA control charts, were generated from the Minitab software16.

According to Montgomery, Runger and Hubele (2004), the values of the upper limit of control (UCL) and lower limit of control (LCL) for the control chart of Shewhart, are calculated using Equations 2 and 3:

$$
\begin{aligned}
& U C L=\overline{\bar{X}}+3 \frac{\bar{R}}{d_{2}} \\
& L C L=\overline{\bar{X}}-3 \frac{\bar{R}}{d_{2}}
\end{aligned}
$$

Where, $\overline{\bar{X}}=$ Average of means; $\bar{R}=$ Average of data amplitudes; $d_{2}=$ constant equal to 1.128 for $n=2$, considering individual measures.

For the CUSUM control plot, the cumulative sum was calculated from Equation 4, where deviations from the mean are accumulated over time.

$$
C_{i}=\sum_{j=1}^{i}\left(x_{j}-\mu_{0}\right)
$$

Where, $C_{i}=$ cumulative sum up to the $i$-th sample; $x_{j}=$ the average of the $j$-th size sample $n \geq 1$ (Montgomery, 2009).

For irrigation, the higher the uniformity of water distribution (DU) the better the system performance. Therefore, the use of the tabular CUSUM control chart that accumulates deviations that are below or above the target value 
(unilateral process), according to Montgomery (2009), is the most indicated. The upper CUSUM $\left(C_{i}^{+}\right)$and the lower CUSUM $\left(C_{i}^{-}\right)$are expressed by Equations 5 and 6 :

$$
\begin{aligned}
& C_{i}^{+}=\max \left[0 ; x_{i}-\left(\mu_{0}+K\right)+C_{i-1}^{+}\right] \\
& C_{i}^{-}=\max \left[0 ;\left(\mu_{0}+K\right)-x_{i}+C_{i-1}^{-}\right]
\end{aligned}
$$

Where, $\mu_{0}=$ sample mean; $x_{i}=$ observation in time; $C_{i}=$ cumulative sum up to the $i$-th sample, which may be negative $C_{i}^{-}$or positive $C_{i}^{+} ; K=$ compensation value or clearance.

For monitoring of averages, it is common to use $K=0.5$, which according to Montgomery (2009), allows to detect specific alterations.

The EWMA control plot consisted of plotting $Z_{i}$ versus sample number $i$ (or time), which according to Montgomery (2009) is calculated by Equation 7.

$$
Z_{i}=\lambda x_{i}+(1-\lambda) Z_{i}-1
$$

Where, $0<\lambda \leq 1 ; Z_{i}=\mu_{0}=\bar{x}$ (target value or mean value in $x_{i}$ control).

The variance of the variable $Z$ is given by Equation 8 :

$$
\sigma_{z i}^{2}=\sigma^{2}\left(\frac{\lambda}{2-\lambda}\right)\left[1-(1-\lambda)^{2 i}\right]
$$

Where, $\sigma=$ standard deviation of the data in relation to the mean; $\lambda=$ weight given to each sample; $i=$ order of the sample used.

Montgomery (2009) states that the upper limit of control $(U C L)$ and lower limit of control $(L C L)$ for the EWMA control chart are calculated by Equations 9 and 10:

$$
\begin{aligned}
U C L & =\bar{x}+L \sigma \sqrt{\frac{\lambda}{2-\lambda}\left[1-(1-\lambda)^{2 i}\right]} \\
L C L & =\bar{x}-L \sigma \sqrt{\frac{\lambda}{2-\lambda}\left[1-(1-\lambda)^{2 i}\right]}
\end{aligned}
$$

Where, $\bar{x}=$ average of the data; $\lambda=$ weight given to each sample, which varies from 0 to $1 ; L=$ number of standard deviations of the control mean to be detected; $i=$ order of the sample used.

In this study was used as weight constant of the sample $\lambda=0.2$ and for width of the limits the factor $L=2$.

To verify if the process (irrigation) was able to remain under control, the process capacity index $\left(C_{p i}\right)$ was calculated for each area from the lower limit of specification (LSL) for DU of $65 \%$, according to with the classification proposed by Keller and Bliesner (2009) that specify as the acceptable minimum for irrigation. According to Montgomery (2009) the index should be above 1.25, for existing processes, as is the case of the present research, is calculated by Equation 11:

$$
C_{p i}=\frac{\bar{x}-L S L}{3 \sigma}
$$

Where, $\bar{x}=$ Average of means; $L S L=$ Lower Specification Limit; $\sigma=$ Standard deviation.

\section{Results and Discussion}

\subsection{Descriptive Statistics of the Data}

Table 1 presents the descriptive statistics of the data collected in areas A and B for water depth $\left(\mathrm{mm} \mathrm{h}^{-1}\right)$, distribution uniformity coefficient $(\%)$ and climatic factors such as temperature $\left({ }^{\circ} \mathrm{C}\right)$, relative humidity $(\%)$ and wind speed $\left(\mathrm{m} \mathrm{s}^{-1}\right)$.

The results were analyzed from the mean, standard deviation, coefficient of variation, minimum and maximum values. 
Table 1. Descriptive statistics of the data

\begin{tabular}{|c|c|c|c|c|c|c|}
\hline & Parameters & Mean & Standard Deviation & Coefficient of variation & Minimum Value & Maximum Value \\
\hline \multirow[t]{2}{*}{ Area A } & Water Depth $\left(\mathrm{mm} \mathrm{h}^{-1}\right)$ & 21.48 & 2.77 & 12.91 & 15.91 & 26.34 \\
\hline & DU $(\%)$ & 68.72 & 6.27 & 9.12 & 57.29 & 82.81 \\
\hline \multirow[t]{2}{*}{ Area B } & Water Depth $\left(\mathrm{mm} \mathrm{h}^{-1}\right)$ & 21.18 & 2.60 & 12.28 & 15.24 & 27.22 \\
\hline & DU (\%) & 70.00 & 5.72 & 8.17 & 59.80 & 79.81 \\
\hline \multirow[t]{3}{*}{ Meteorological data } & Temperature $\left({ }^{\circ} \mathrm{C}\right)$ & 26.56 & 3.72 & 14.00 & 18.57 & 31.65 \\
\hline & Humidity (\%) & 65.39 & 13.07 & 19.98 & 41.33 & 88.00 \\
\hline & Wind $\left(\mathrm{m} \mathrm{s}^{-1}\right)$ & 3.85 & 1.80 & 46.65 & 0.57 & 8.50 \\
\hline
\end{tabular}

Note. $\mathrm{DU}=$ distribution uniformity coefficients.

In both areas, the mean, standard deviation, coefficients of variation, minimum and maximum values corresponding to the values of the water depth and the uniformities of distribution (DU) were equivalent. However, DU of area B (70\%) was greater in relation to area A (68.72\%), both being classified as acceptable, according to Keller and Bliesner (2009).

Ribeiro et al. (2012) when studying the distribution of water depth in a fixed sprinkler irrigation system, obtained DU equal to $70.80 \%$ using a pressure of 2.8 bar without the interference of the diffuser pin. The authors justified the low performance because the sprinklers were tested in field conditions and under the influence of non-controllable climatic factors.

Although the average wind speed was $3.85 \mathrm{~m} \mathrm{~s}^{-1}$, it ranged from 0.57 (recorded at $17: 00 \mathrm{pm}$ ) to $8.50 \mathrm{~m} \mathrm{~s}^{-1}$ (recorded at 8:00 am), with the highest CV (46.65\%). Zhang, Merkley and Pinthong (2013) state that when the wind speed exceeds the value of 1.8 to $2.0 \mathrm{~m} \mathrm{~s}^{-1}$, the uniformity of water distribution can significantly reduce. Thus, it is possible that the low values of DU were caused by the high wind speed recorded in several tests.

The variation in the temperature and relative humidity of the air can be justified by the period of realization the tests, that is, in the morning periods the temperatures were lower with high relative humidity of the air than in the afternoon.

To represent the average amount of water contained in the collectors in 25 test, with duration of 1 hour in the two study areas (A and B), it was proposed to Figure 4. The water overlap between the four sprinklers is shown with the influence of the sprinklers 3 and 8 in as well as the prevailing wind direction during the trials.

Area A

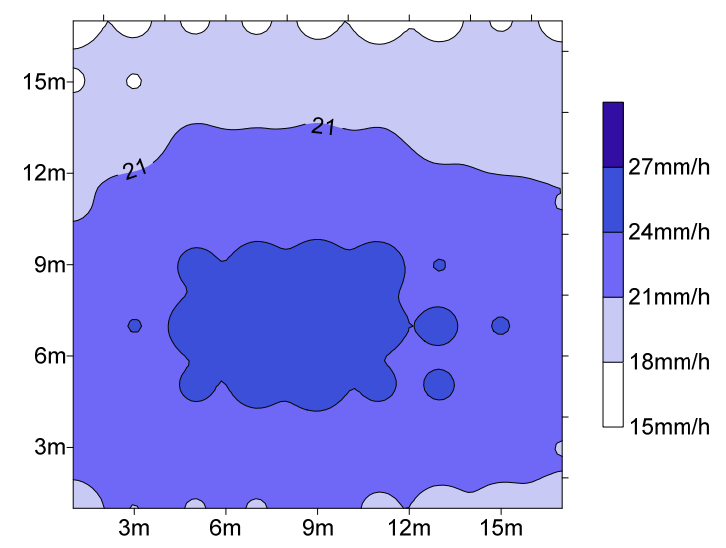

Area B

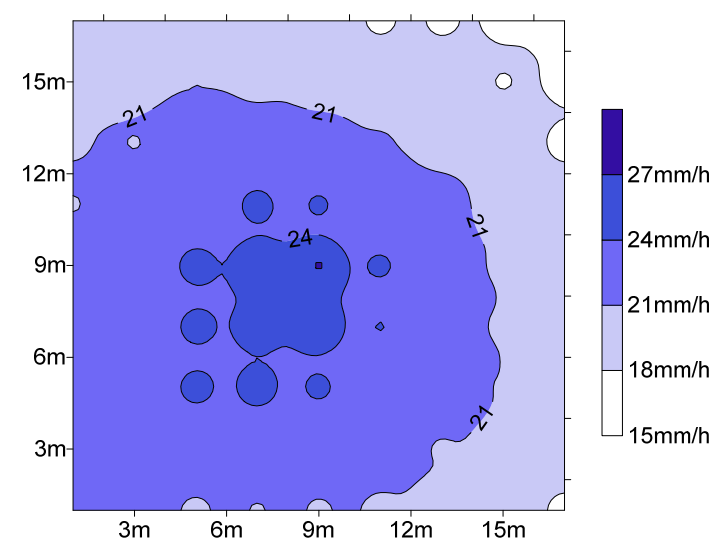

Figure 4. Representation of water depth variability in areas A and B

It should be noted that the characteristics of the graphs referring to areas A and B are similar. The largest water depths are distributed near the center of the areas, place of water overlap between the four sprinklers. However, the largest water depths are displaced from the center, due to the influence of the north wind that prevailed during the 25 trials. 
In both areas, it can be observed that the smaller amounts of water are located near the sprinklers 1, 2, 5 and 10, which may also have been influenced by the predominant wind.

Comparing the mean values of the water depth of areas A and B, it was verified that the amplitude in area B was higher, in which the minimum value was $15.24 \mathrm{~mm} \mathrm{~h}^{-1}$ and the maximum value was $27.22 \mathrm{~mm} \mathrm{~h}^{-1}$. These values can be justified by the different sprinkler pressures, which according to Zhang, Merkley and Pinthong (2013) can result in different water distribution profiles and different overlapping patterns. It should be noted that the mean pressures obtained in each sprinkler were $184 \mathrm{kPa}$, which ranged from 167 to $203 \mathrm{kPa}$.

The Minitab 16 software was used to perform the regression analysis between the values of DU (\%) and wind speeds of areas $\mathrm{A}$ and $\mathrm{B}\left(\mathrm{m} \mathrm{s}^{-1}\right)$, from which Table 2 was obtained, which presents the equations and their respective coefficients of determination.

Table 2. Regression analysis between DU values and wind speed

\begin{tabular}{lll}
\hline & Equation & $\mathrm{R}^{2}$ \\
\hline Area A & DU (A) $=80.71-3.115 \cdot$ Wind & $79.66 \%$ \\
Area B & DU (B) $=77.52-1.954 \cdot$ Wind & $37.64 \%$ \\
\hline
\end{tabular}

Note. DU (A) = uniformity of distribution of area A and DU $(\mathrm{B})=$ uniformity of distribution of area B.

According to the obtained equations, it is observed that in the two areas, the uniformity of distribution reduces when the wind speed increases. However, in area A, the value of DU suffers greatest reduction in relation to area $B$ when an increase in wind speed occurs. In addition, the value of the coefficient of determination (R2) for area A was greater in relation to area $\mathrm{B}$, indicating that the model is more explanatory and presents better fit for the data in question in relation to the equation obtained for area $\mathrm{B}$.

Claro, Costa, and Machado (2007), report that the positive correlation within the subgroups significantly affects the performance of the graphs. It also states that the EWMA graph is substantially more agile than Shewhart's in detecting process disturbances, especially when they generate small mismatches in the mean.

For Mingoti and Yassukawa (2008), the greater the autocorrelation, the more indicated is the Shewhart graph, however, they claim that the CUSUM and EWMA graphs are not suitable for autocorrelated processes since they present a high false alarm value, thus generating a large number of unnecessary interventions in the process.

In this way, the software Minitab 16 was used to analyze the autocorrelation as a function of the uniformity of distribution (DU) and wind speed, which are represented by Figure 5. 

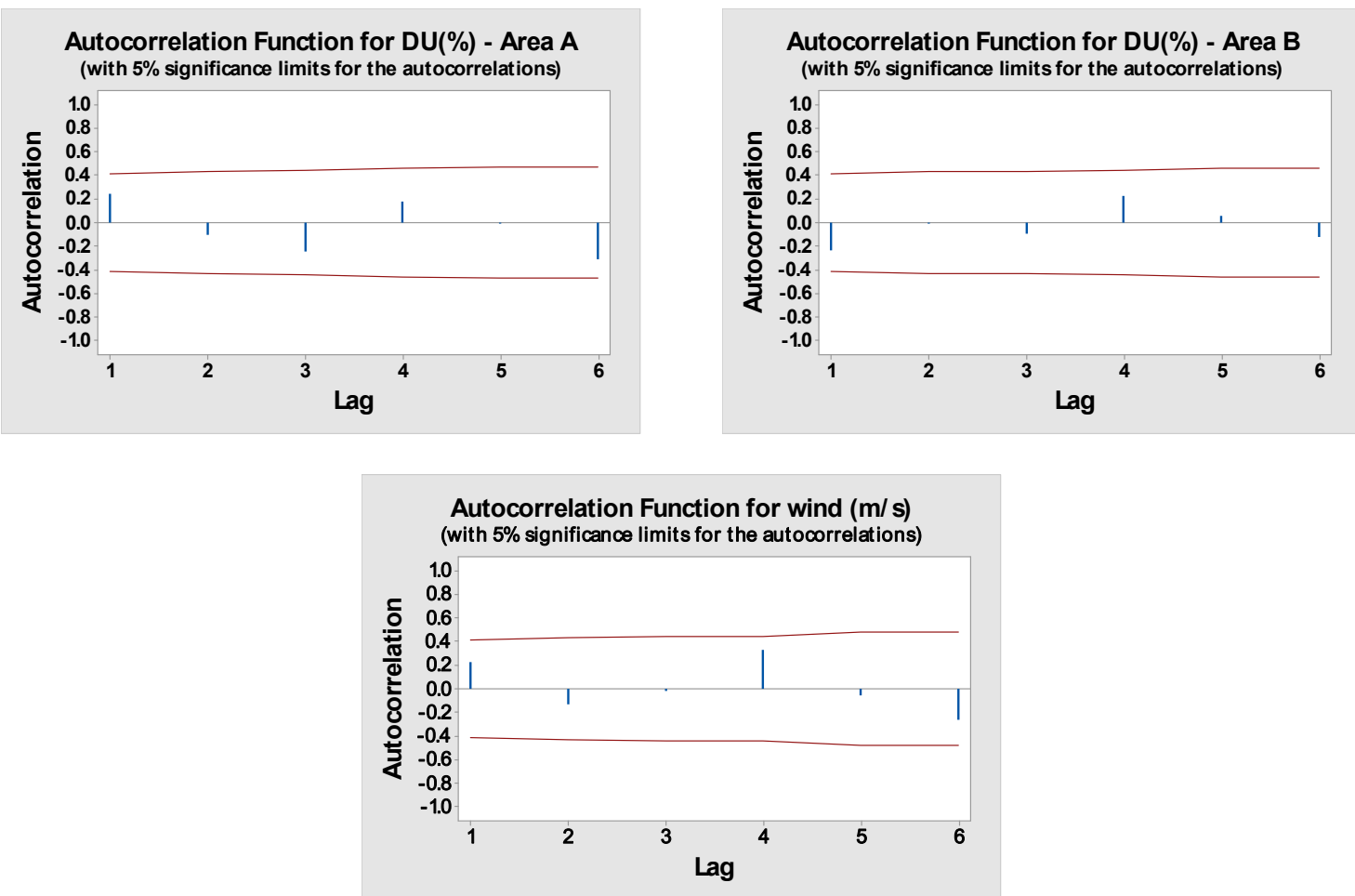

Figure 5. Autocorrelation as a function of DU and wind speed of areas A and B

No autocorrelation was identified as a function of the uniformity of distribution (DU) of area A and B and wind speed, thus, it is possible to apply Shewhart, CUSUM and EWMA control charts.

Figure 6 shows the Shewhart chart for individual measurements corresponding to the uniformity of distribution (DU) with respect to areas A and B, which according to Keller and Bliesner (2009) the minimum acceptable value is $65 \%$. Figure 7 presents the graph related to the wind velocity indicating the value of $2 \mathrm{~m} \mathrm{~s}^{-1}$, which corresponds to the speed at which the distribution uniformity reduces significantly according to Zhang, Merkley and Pinthong (2013).
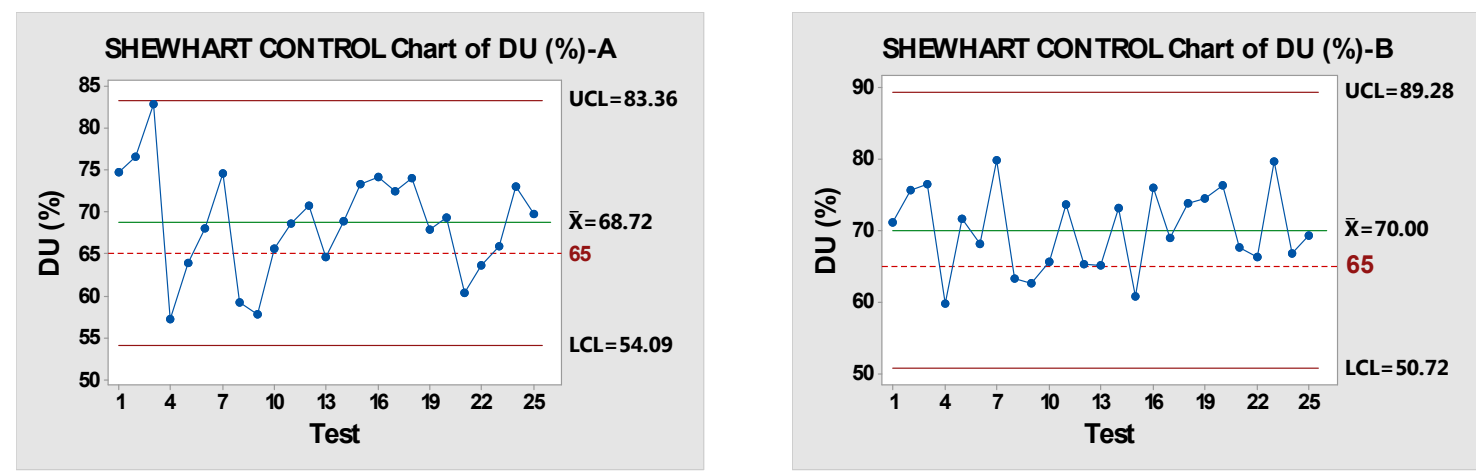

Figure 6. Shewhart control chart for distribution uniformity (DU) in areas A and B 


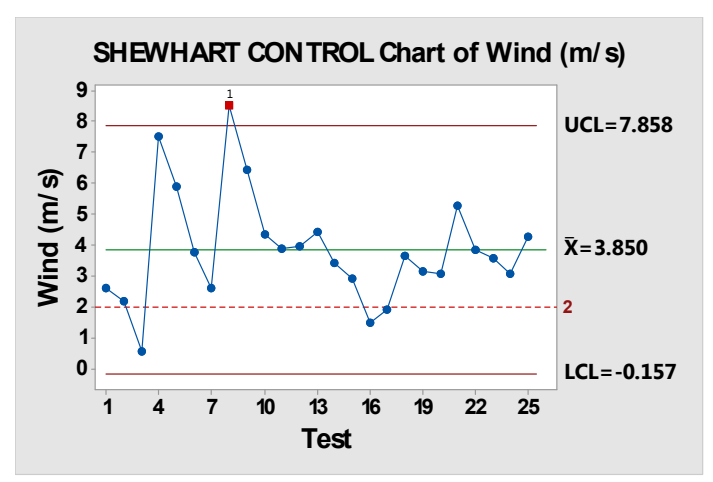

Figure 7. Shewhart control chart for wind speed

For both areas (A and B), the graph indicated that the process is under control, with all points plotted between the control limits. However, the graph of area A presents some points distant from the midline, unlike the graph of area B.

The highest irrigation uniformity in areas $\mathrm{A}$ and $\mathrm{B}$, simultaneously, were obtained in trials 3,7 and 16 , in which wind velocity was recorded, with $0.6,2.6,1.5 \mathrm{~m} \mathrm{~s}^{-1}$, respectively. This fact indicated that at low speeds, uniformity of distribution tends to increase.

On the other hand, the low uniformities in areas A and B were obtained in trials 4, 8 and 9 , which can be justified by high wind speeds, whose values were 7.5, 8.5 and $6.4 \mathrm{~m} \mathrm{~s}^{-1}$, respectively. For Frigo et al. (2016), the control charts for conventional irrigation indicated that the process was out of control at the point where the wind speed was equal to or greater than $2.63 \mathrm{~m} \mathrm{~s}^{-1}$, that is, the wind speed, although lower to the present study, significantly affected the uniformity of water distribution.

With regard to the minimum acceptable value of $65 \%$ for DU, by classification of Keller and Bliesner (2009), it is verified that in area B only four trials had DU below this minimum value and seven tests in area $\mathrm{A}$.

The EWMA control charts for DU with respect to areas A and B are shown in Figure 8, also with a minimum acceptable value of $65 \%$. And, in Figure 9, the graph corresponding to the wind velocity with the indication of winds of $2 \mathrm{~m} \mathrm{~s}^{-1}$ is presented.
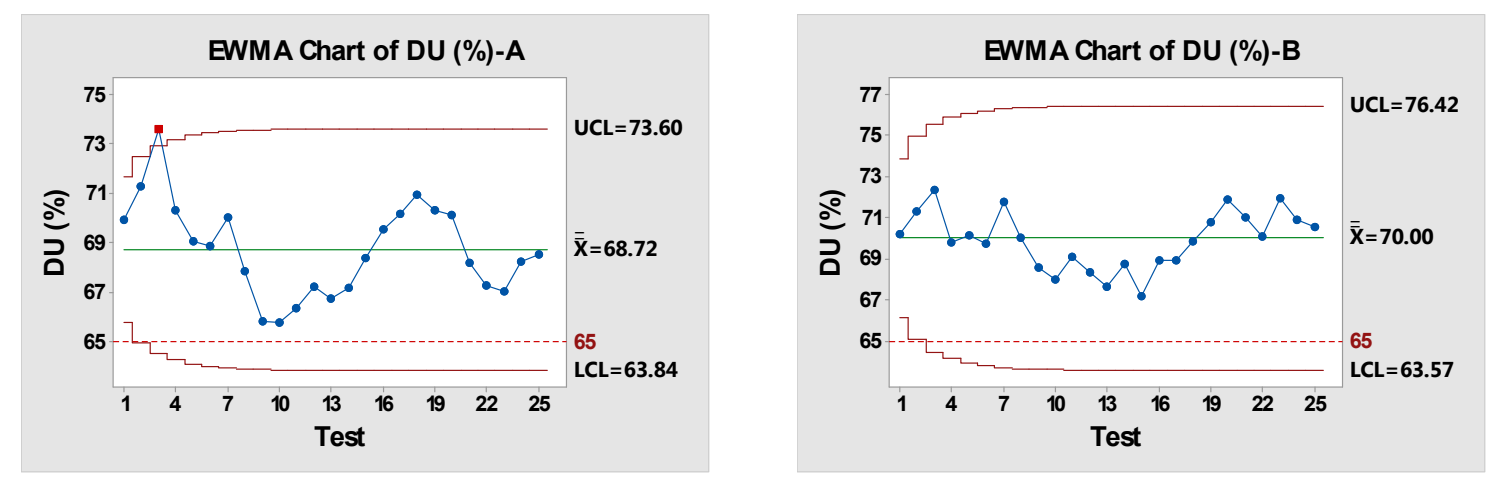

Figure 8. EWMA control chart for distribution uniformity (DU) in areas A and B 


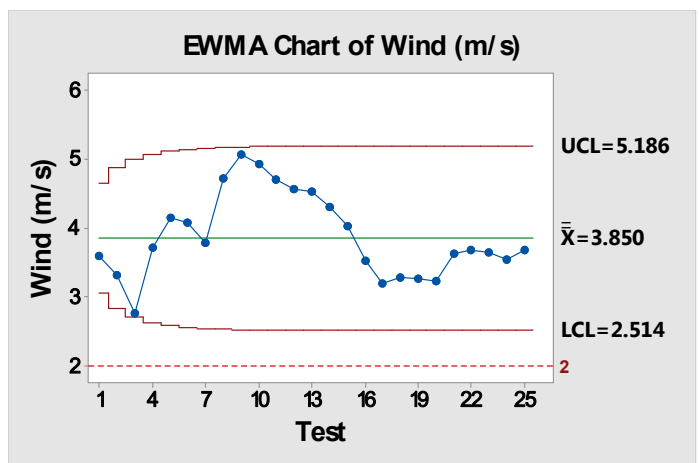

Figure 9. EWMA control chart for the wind

It is observed that in the graph of area A, test 3 is above the upper control limit. In addition, most of the points plotted are distant from the midline, with a decreasing trend. A sequence of eight trials below the midline (assay 8 to 15) was also identified, which according to Montgomery, Runger, and Hubele (2004) is indicative of an out-of-control process.

In relation to test 9 and 10, with the lowest exponentially weighted moving average of DU, it can be justified by the high moving average in relation to the wind speed. Unlike assay 3, that had the highest EWMA of DU with the lowest moving average in relation to wind speed.

The graph of area B, although not showing points outside the control limits, showed a sequence of 10 tests below the midline (test 9 to 18), also indicating that it was out of control. Mercante et al. (2014) also concluded from the control plot that the parameters studied were out of control due to the behavior in sequence form on the same side of the midline.

For Andrade et al. (2017), the EWMA control chart provided a more accurate and adequate diagnosis for micro-sprinkler irrigation, which detected small variations, diagnosed from sequences below the midline.

The CUSUM control chart for distribution uniformity (DU), in areas A and B, are shown in Figure 10. In Figure 11 the graph is presented in relation to the wind speed.
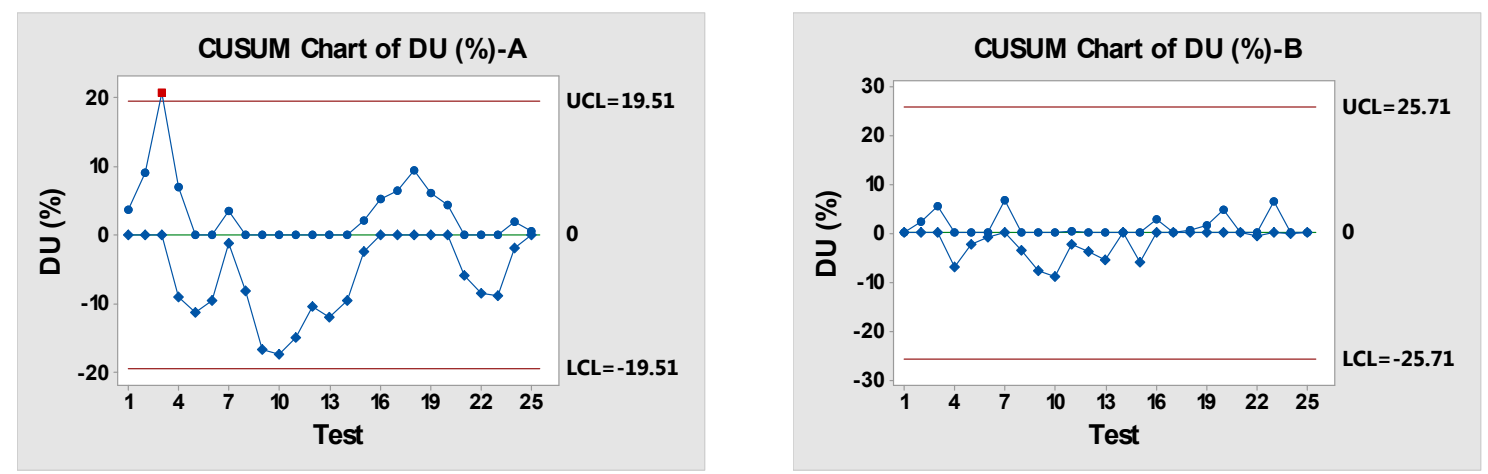

Figure 10. CUSUM control chart for distribution uniformity (DU) in areas A and B 


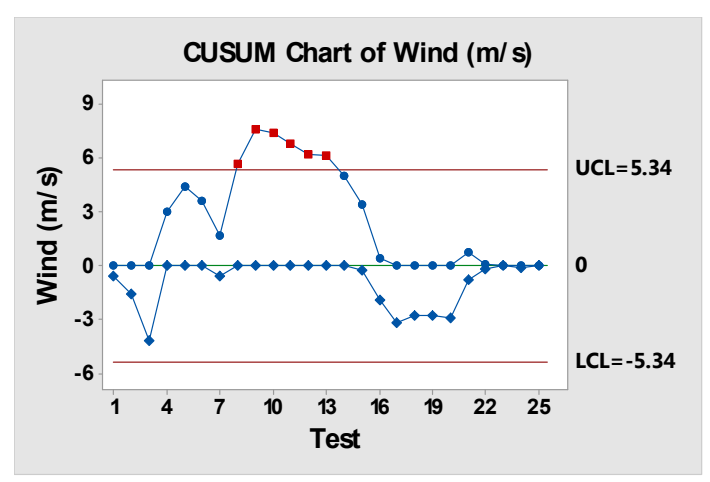

Figure 11. CUSUM control chart for wind speed

As in the previous charts for area A the CUSUM control graphs also indicated that the process is out of control, with assay uniformity 3 above the upper control limit and sequence of 12 assays below the midline (assays 4 to 15). Test 3 , with the highest cumulative sum in relation to DU, can be justified by the low cumulative sum in relation to wind speed. On the other hand, it is noticed that the higher sums accumulated in the wind speeds, above the UCL, are associated with the lowest accumulated sums of DU.

The CUSUM control graphs for irrigation uniformity of micro-sprinklers obtained by Andrade et al. (2017) also identified out-of-control treatments by displaying distant points in relation to the midline, presenting a sequence of more than eight points below the midline with low and high tendency at different times.

The control chart of area B indicated that the process is under control, not presenting abnormal behavior that could be considered out of control.

Overall, the Shewhart control charts indicated that both areas are under statistical control. Unlike the EWMA control chart, it indicated both areas out of control. The CUSUM control chart indicated that area B is under control.

For Frigo et al. (2016) due to the simplicity, robustness and ease of interpretation of the data in conventional sprinkler irrigation systems, Shewhart's graphs compared to the CUSUM and EWMA charts were the most indicated. On the other hand, Andrade et al. (2017) indicated the EWMA and CUSUM graphs for analysis of irrigation uniformity by micro-sprinklers because of their accuracy in detecting small variations.

To identify the areas (A or B) in which the irrigations are capable of being kept under control, the process capacity indices (Cpi) were calculated, which are found in Table 3, emphasizing that the process is only able to remain under control, when the Cpi value is greater than 1.25 for existing processes, according to Montgomery (2009).

Table 3. Process capability index for uniformity of distribution (DU)

\begin{tabular}{lll}
\hline \multicolumn{2}{l}{ Process capability index for DU $(\%)-\mathrm{LSL}=65 \%$} \\
\hline Area & A & B \\
\hline Cpi & 0.25 & 0.26 \\
\hline
\end{tabular}

Note. $\mathrm{DU}=$ Distribution Uniformity; LSL $=$ Lower Specification Limit.

From the low values of process capability indices below 1.25, the irrigations of areas A and B were not able to remain under control over time.

These values are justified by the influence of the climatic factors, mainly by the effect of the wind during the tests, which reached the maximum speed of $8.5 \mathrm{~m} \mathrm{~s}^{-1}$.

Ribeiro et al. (2012), reports that among the climatic factors, the wind was the factor that most influenced the uniformity of water distribution. Faria et al. (2016), Justi, Vilas Boas and Sampaio (2010) and Frigo et al. (2013) which state that with increasing wind speed, the uniformity of water distribution decreases, made the same report. 
In a survey for sprinkler irrigation evaluation, Justi, Vilas Boas and Sampaio (2010) concluded that the process capability index was directly proportional to the uniformity of distribution.

\section{Conclusion}

Although the ease of interpretation of the Shewhart control plot is an important feature for analysis, it was inefficient when no abnormality was detected in the process. On the other hand, the Cussum graph was more efficient because it detected abnormality in at least one of the processes. Already, by the EWMA graph, small variations in the uniformity of water distribution in areas A and B was detected, identifying the occurrence of abnormality in both areas and, therefore, the most suitable for the evaluation of the process.

Due to the low uniformity of water application, in areas A and B, caused mainly by the high wind speed, besides the irrigations being out of control, they also did not have the capacity to stay under control over time.

The application of quality tools is an important ally in identifying failures in water application uniformities. Thus, to obtain irrigation under control and with the capacity to maintain it over time, it is necessary to investigate the causes of these faults and correct them. For this, it is recommended to use these tools periodically from new proposals of tests.

Due to the high-water requirements on soccer field lawns, it is essential that the flaws in the uniformity of application by the irrigation system be corrected, to obtain a uniform lawn in all its extension, applying only a volume of water necessary for its economy.

\section{References}

ABNT (Brazilian Association of Technical Standards). (2000). NBR ISO 7749-2. Agricultural irrigation equipment-rotary sprinklers (p. 6). Part 2: Uniformity and distribution and test methods. Retrieved from https:/www.target.com.br/produtos/normas-tecnicas/30334/nbriso7749-1-equipamentos-de-irrigacao-agrico la-aspersores-parte-1-requisitos-para-projetos-e-operation

Andrade, M. G., Vilas Boas, M. A., Siqueira, J. A. C., Dieter, J., Sato, M., Hermes, E., ... Tokura, L. K. (2017). Statistical quality control for evaluation of uniformity of microsprinkler irrigation with photovoltaic solar energy. Renewable and Sustainable Energy Reviews, 78, 743-753, https://doi.org/10.1016/j.rser.2017. 05.012

Atroosh, K. B., Al-Khader Ahmed, G., Lardi, O. S., Eissa, Z. A., \& Belgacem, A. O. (2018). Yield and Irrigation Water Productivity of Three Varieties of Buffel Grass (Cenchrus ciliaris L.) in the Southern Coastal Plains of Yemen. Journal of Agricultural Science, 10(1), 114-121. https://doi.org/10.5539/jas.v10n1p114

Bernardo, S. (1995). Irrigation manual (8th ed., p. 657). Viçosa: Impr. Univ.

Claro, F. A. E., Costa, A. F. B., \& Machado, M. A. G. (2007). EWMA and $\bar{X}$ control charts for the monitoring of autocorrelated processes. Produção, 17, 536-546, https://doi.org/10.1590/S0103-65132007000300010

Coelho, A. P., Dalri, A. B., Landell, E. P. A., Fischer Filho, J. A., Libardi, L. G. P., Bettiol, J. V. T., ... Palaretti, L. F. (2018). Productivity, Technological Attributes and Water Use Efficiency of Sugarcane Cultivars Under Regulated Deficit Irrigation. Journal of Agricultural Science, 10(7), 174-183, https://doi.org/10.5539/ jas.v10n 7 p 174

Costa, A. F. B., Epprecht, E. K., \& Carpinetti, L. C. R. (2005). Statistical quality control (2nd ed.). São Paulo: Atlas.

Faria, L. C., Beskow, S., Colombo, A., Nörenberg, B. G., Neto, O. R., \& Simões, M. C. (2016). Influence of the wind on water application uniformity of a mechanical lateral move irrigation equipment using rotating plate sprinklers. Ciência Rural, 46, 83-88, https://doi.org/10.1590/0103-8478cr20141558

Frigo, J. P., Vilas Boas, M. A., Frigo, E. P., Hermes, E., \& Tessaro, E. (2013). Day and night irrigation in a conventional sprinkler system em Palotina, Paraná. Irriga, 18, 318-327. Retrieved from http://irriga.fca.unesp.br/index.php/irriga/article/view/545

Frigo, J. P., Vilas Boas, M. A., Frigo, J. P., \& Frigo, E. P. (2016). Comparison between Shewhart control charts, CUSUM and MMEP in process of conventional irrigation sprinkler. Irriga, Edição Especial, 56-70. https://doi.org/10.15809/irriga.2016v1n01p56-70

García-González, J. F., Moreno, M. A., Molina, J. M., Madueño, A., \& Ruiz-Canales, A. (2015). Use of software to model the water and energy use of an irrigation pipe network on a golf course. Agricultural Water Management, 151, 37-42, https://doi.org/10.1016/j.agwat.2014.11.012 
Justi, A. L., Vilas Boas, M. A., \& Sampaio, S. C. (2010). Process capacity index in the uniformity evaluation of sprinkler irrigation. Engenharia Agricola, 30, 264-270, https://doi.org/10.1590/S0100-69162010000200008

Keller, J., \& Bliesner, R. D. (2009). Sprinkle and Trickle Irrigation (p. 314). Utah State University: Chapman-Hall, Publishers.

Mantovani, E. C., Bernardo, S., \& Palaretti, L. F. (2007). Irrigation, principles and methods (2nd ed., p. 358). Viçosa: Ed. UFV.

Mercante, E., Vilas Boas, M. A., Silva, B. B., \& Klein, M. R. (2014). Use of statistical control charts in irrigation. Electronic Journal of the Master in Environmental Education, V(Special), 97-108. Retrieved from http://www.academia.edu/23319860/Utilização_de_gráficos_de_controle_estatístico_na_irrigação

Mingoti, S. A., \& Yassukawa, F. R. S. (2008). A comparison of control charts for the mean of autocorrelated processes. Systems \& Management, 3, 55-73. Retrieved from http://www.revistasg.uff.br/index.php/sg/ issue/view/9

Montgomery, D. C. (2009). Introduction to Estatistical Quality Control (6th ed., p. 754). Arizona.

Montgomery, D. C., Runger, G. C., \& Hubele, N. F. (2004). Chapter 8: Statistical Quality Control. Statistics Applied to Engineering (2nd ed., pp. 279-309). LTC-Technical Books and Scientific Publishing.

Ribeiro, D. C. C., Silva, N. F., Cunha, F. N., Teixeira, M. B., Soares, F. A. L., \& Gomes, R. R. (2012). Distribution of water depth in a fixed sprinkler system. Brazilian Journal of Irrigated Agriculture, 6, 144-150. https://doi.org/10.7127/rbai.v6n200365

Saldanha, P., Rothe, C. K., Pacheco, D. A. J., Jung, C. F., \& Caten, C. S. (2015). Contributions of use statistical process control in the performance analysis of the chemical industry. Revista Ingeniería Industrial, 14, 37-50. Retrieved from https://issuu.com/revistaingenieriaindustrial/docs/revista_ingenieria_industrial_ v14_1/38

Zhang, L., \& Merkley, G. P. (2012). Relationships between common irrigation application uniformity indicators. Irrigation Science, 30, 83-88. https://doi.org/10.1007/s00271-011-0264-6

Zhang, L., Merkley, G. P., \& Pinthong, K. (2013). Assessing whole-filed sprinkler irrigation application uniformity. Irrigation Science, 31, 87-105. https://doi.org/10.1007/s00271-011-0294-0

\section{Copyrights}

Copyright for this article is retained by the author (s), with first publication rights granted to the journal.

This is an open-access article distributed under the terms and conditions of the Creative Commons Attribution license (http://creativecommons.org/licenses/by/4.0/). 